\title{
Öğrencilerin Muhasebe Eğitiminden Beklentileri Ve Motivasyonlari: Ağri İli Örneği
}

\author{
Expectations And Motivations Of Accounting Students From Accounting Education: \\ Ağrı Province Case
}

\author{
Ümmü Gülsüm ASLAN ${ }^{1}$ - Dr. Öğr. Üyesi Utku ŞENDURUR ${ }^{2}$
}

\begin{abstract}
ÖZET
Bu çalışmanın amacı Üniversite ve Mesleki ve Teknik Anadolu Lisesi son sınıf öğrencilerin muhasebe eğitiminden beklentileri ve motivasyonlarına yönelik problemleri tespit etmek ve bu problemlere yönelik çözüm önerileri sunmaktır. Öğrencilerin muhasebe eğitiminden beklentilerini ve motivasyonlarını belirlemek için toplam 119 öğrenciye anket uygulanmıştır. Ankette elde edilen veriler yüzde, frekans ve t-testi ile analiz edilmiştir. Çalışmanın sonucunda öğrencilerin üniversiteden mezun olma konusunda motivasyonlarının yüksek olduğu, muhasebe hakkında daha çok şey öğrenmek istedikleri ve bu bölümden mezun olunca kendilerine olan güvenlerinin $\operatorname{arttığı}$, kendilerini geliştirmek için istekli oldukları fakat sınavlar içinse kaygılı oldukları görülmüştür. Ayrıca öğrencilerin muhasebe dersinden beklentileri ve kendine güvenleri açısından mezuniyet değişkeni ve kendine güvenleri açısından ise sadece staj yapma değişkeni grupları arasında ortalamalar bakımından anlamlı farklılıklar olduğu tespit edilmiştir.
\end{abstract}

Anahtar Kelimeler: Muhasebe Eğitimi, Motivasyon, Anket, Yüzde ve Frekans Analizi, T-testi.

\begin{abstract}
The aim of this study is to identify the problems regarding the expectations and motivations of the senior students of the University and Vocational and Technical Anatolian High School from accounting education and attempt to suggest solutions to these problems. A survey for 119 senior grade students is conducted to determine their expectations and motivations from accounting education. Frequency, proportion, mean analysis and $\mathrm{t}-$ test is done. According to results of the study it is determined that, students have high motivations about graduation from university, they want to learn more about accounting, when they graduate from this department, they have more confidence in themselves and they are eager to improve themselves but anxious about the exams. Besides, it is determined that, there are statistically significant differences between the groups of graduation variable with regard to expectations from accounting education and self confidence and between the groups of doing internship variable with regard to self confidence.
\end{abstract}

Key Words: Accounting Education, Motivation, Survey, Frequency and Proportion Analysis, T-test

\section{GİRIŞ}

Eğitim en yüzeysel anlamıyla bireyin hayatında kendi tecrübeleri ile elde ettiği veya elde etmek istediği bilgileri ve tecrübeleri öğrenme sürecidir (Aksoy \& Özkan, 2015, s. 283-305). Muhasebe, işletmelerin mali işlemlerini kaydeden sınıflandıran, özetleyen ve raporlayan bilimsel bir metodudur

\footnotetext{
${ }^{1}$ Yüksek Lisans Öğrencisi, Ağrı İbrahim Çeçen Üniversitesi, Muhasebe Finansman ABD,

e-Mail: ummugulsumaslan0@gmail.com, ORCID No: 0000-0002-1927-0823

${ }^{2}$ Ağrı İbrahim Çeçen Üniversitesi, Muhasebe Finansman ABD, E mail: usendurur@agri.edu.tr,

ORCID No: 0000-0002-8303-4315
} 
(İmamoğlu, 2016, s. 3). Eğitim ve muhasebe tanımları 1şı̆̆ında muhasebe eğitimi; kişinin muhasebe alanında ilerleyebilmek ve bu mesleği icra edebilmek için aldığı eğitim sürecini ifade etmektedir. Türkiye'de muhasebe eğitimi ilk olarak lise döneminde başlamakta ve bu sürecin devamını yüksekokul ve üniversite takip etmektedir.

Uzun, zorlu ve yorucu bir süreç olan eğitim sürecinde öğrencilerin beklentileri ve ilgilenimleri de oldukça karmaşık bir durumda olabilir. Bu karmaşıklığın öğrencilerin motivasyon ve beklentilerini etkilediği düşünülmektedir (Zeytinoğlu, 2012, s. 103-116). Öğrencilere kaliteli bir eğitim verilebilmesi için en önemli hususlardan biri öğrencilerin isteklerini göz önüne alarak eğitim sürecine dahil edilmesidir. Öğrencinin istek ve ihtiyaçlarının dikkate alınmadığ durumlarda öğrenciye verilen eğitimde istenilen faydanın görülemeyeceği düşünülmektedir. $\mathrm{Bu}$ durumda yapılması gereken öğrencilerin ne istediklerini bilmelerini sağlamaktır. Ülkemizde öğrencilerin ne istediklerini eğitim sürecindeki beklentilerinin tespiti adına araştırmalar ve çalışmalar yapıldığını söyleyemeyiz. Gerekli çalışmaların yapılmadığını diğer ülkelerde yapılan çalışmalar ile kıyasladığımızda ortaya daha belirgin bir şekilde çıkmaktadır (Zeytinoğlu, 2012, s. 103-116).

Çalışmanın amacı son sınıf Mesleki ve Teknik Anadolu Lisesi ve Üniversite öğrencilerinin muhasebe eğitiminden beklenti ve motivasyonlarına etki eden faktörleri tespit etmek ve bu konulara ilişkin çözüm önerileri getirmektir. Literatürde yer alan çalışmalar incelendiğinde öğrencilerin muhasebe eğitiminden beklentileri ve motivasyonlarına ilişkin benzeri çalışmaların az sayıda olduğu görülmüştür. Yapılan bu çalışma kısmen de olsa yol gösterici olması açısından önemli olduğu düşünülmektedir.

$\mathrm{Bu}$ çalışmada muhasebe alanında eğitim alan Mesleki ve Teknik Anadolu Liseleri ve Üniversite öğrencilerinin muhasebe eğitimine karşı motivasyon ve beklentilerini, muhasebe ilgilenim düzeylerini ve muhasebecilik mesleğinin gerektirdiği yeterliklere ne ölçüde sahip olduklarını tespit etmek ve birtakım çözüm önerileri getirmek amacıyla yapılmıştır.

\section{LITERATÜR TARAMASI}

Saemann ve Crooker (1999, s. 1-22) ayrı zaman sürelerinde iki aşamalı olarak öğrencilerin okula başladıktan sonraki 2. ve 15. haftalarında ayrı ayrı çalışmalar yapmışlardır. 2. haftada yapılan çalışmaya 283 öğrenci, 15.haftada yapılan çalışmaya 234 öğrenci katılmıştır. 2.haftada yapılan çalışmada öğrencilerin muhasebe bölümü seçmeleri konusunda kararsızlık söz konusu iken 15.haftada yapılan çalışmada muhasebe konularının çokluğu öğrencilerin bu bölüm ile ilgili cesaretlerini kırıldı̆̆ tespit edilmiştir.

Cook ve Leckey (1999) üniversite öğrencilerinin ortaöğretimden yükseköğretime geçiş sürecini dikkate alarak üniversite yaşamından beklentileri ile öğrenmeye yönelik tavırları hakkında bir araştırma yapmıştır. Araştırma sonuçlarına göre, öğrenciler birlikte yaratmayı sevmişler, takdir etmişler ve bunun olumlu bir öğrenme deneyimi olduğunu hissetmişlerdir.

Donald (1999)'ın yaptığı çalışmanın amacı öğrencilerin motivasyonu ve bunun üst düzey öğrenme ile arasındaki ilişkinin anlaşılmasına yardımcı olmaktır.

Acat ve Yenilmez (2004) eğitim fakültesi öğrencilerinin motivasyon kaynakları ve sorunları ile bunların çeşitli değişkenler açısından farklılaşma durumunu belirlemeye çalışmışlardır. Araştırma sonuçlarına göre, eğitim fakültesi öğrencilerinin genel olarak olumlu motivasyon yüklenmiş oldukları, motivasyon sorunu oluşturan durumları daha az yaşadıkları görülmektedir.

Bryne ve Flood (2005, s. 111-124) muhasebe öğrencilerinin motivasyon ve beklentilerini bu bölümü seçme nedenlerini araştırmışlardır. Muhasebe dersi gören öğrenciler için hangi faktörlerin öncelikli 
olduğu araştırılan çalışmada, daha kaliteli bir muhasebe eğitimi için değişim olması gerektiği vurgulanmıştır.

Tan ve Fawzi (2006, s. 167-187) muhasebe öğrencilerinin bu bölümü seçmelerinde öğrencinin karakterinin, öğrenciyi yönlendiren kişilerin ve ailenin etkili olduğu tespit edilmiştir.

Kaya (2007, s. 125-133) muhasebe öğrencilerinin bir dönem içerindeki algılamalarını etkileyen faktörleri incelendiği bu çalışmada, öğrencilerin dönem başı ve dönemin sonunda algılamalarında büyük bir değişiklik olduğu tespit edilmiştir. Muhasebe dersinin zaman alıcı ve zorlayıcı bir ders olduğu konusunda öğrencilerin aynı düşünceye sahip oldukları belirlenmiştir.

Taylor ve Mander (2007) yaptıkları çalışmada matematik bölümü esas alınarak üniversiteye yeni başlayacak olan öğrencilerin davranışlarını, beklentilerini ve algılamalarını araştırmışlardır. Araştırma sonuçları, kampüs içi öğrencilerin uzaktan eğitim öğrencilerine göre önemli ölçüde daha az zaman harcadıklarını, her iki grubun da müfredat tasarımcıları tarafından beklenenden daha az saat çalıştığını göstermektedir.

Şahin vd. (2011, s. 429-452) üniversite öğrencilerinin kariyer hedeflerini, yaşam beklentilerini, eğitim gördükleri bölüm ile ilgili memnuniyet ve beklentilerine yönelik bir araştırma yapılmışlardır. Yapılan araştırmanın sonuçlarına göre; öğrencilerin yaşamlarında en çok önemsedikleri amaç özel yetenek ve eğitimlerini kullanma isteğidir. Öğrencilerin yarısından fazlası lisansüstü eğitim almayı hedeflemektedir. Okudukları bölümü tercih etmelerindeki en büyük sebep ise mezun olunca iş bulma konusunda zorlanmayacaklarını düşünmeleri ve okudukları bölümü sevmelerinin etkili olduğu tespit edilmiştir. Öğrencilerin yarısının öğrenim gördükleri alandaki yaşantılarından memnun oldukları belirlenmiştir.

Zeytinoğlu (2012, s. 103-116) muhasebe öğrencilerinin yükseköğrenimden beklentilerini, üniversite eğitiminde kendilerine ne kadar güvenliklerini ölçen bir araştırılma yapmıştır. Araştırmada öğrencileri motive eden unsurların muhasebe bölümünün öğrencilerinin gelecek beklentileri karşıladığ1 sportif ve sosyal aktivitelerin öğrencinin bu bölümü seçmelerinde motive edici olmadığ ve öğrencilerin bu bölümü seçme sebeplerinin muhasebe bilgilerini bir üst düzeye taşımak olduğu belirtilmiştir.

Dursun ve Aytaç (2012, s. 373-388) son sınıf üniversite öğrencilerinin kaygı ve umutsuzluk seviyelerini belirlemek, ögrencinin iş hayatına yönelik beklentileri ve iş tecrübesi ile durumluksürekli kaygı ve umutsuzluk arasında bir ilişki olup olmadığına dair araştırma yapmışlardır. Araştırmanın sonucunda öğrencilerin en büyük kaygısının gelecek kaygısı ve mezun olduklarında iş bulmama endişesinde olduğu tespit edilmiştir. Kaygı ve umutsuzluğu az çıkan öğrencilerin ise daha önce iş tecrübesi yaşayan öğrenciler olduğu belirlenmiştir.

İbicioğlu vd. (2013, s. 93-105) muhasebe meslek mensuplarının çalışma süreçlerinde motivasyonlarını etkileyen içsel ve dışsal faktörlerin araştırılması ve hangi motivasyon çeşidinden daha çok etkilendiklerini saplamaya yönelik bir çalışılma yapmışlardır. Çalışmada aynı zamanda demografik özellik farklılıklarının içsel ve dışsal motivasyona etki edip etmediği araştırılmıştır. Yapılan anket sonuçlarına göre muhasebe meslek mensuplarının içsel faktörlerin daha çok etki ettiği tespit edilmiştir. Ayrıca demografik özelliklerin herhangi bir farklılık oluşturmadığı ancak gelir düzeyi yüksek ve iş yeri sahibi konumunda olanların dışsal faktörlerin daha çok güdülediği tespit edilmiştir.

Çarıkçı (2017, s. 1223-1233) çalışmasında, önlisans ve lisans muhasebe eğitimi alacak olan öğrencilerin bu bölüme yönelik motivasyonlarını incelemiş, öğrencilerin muhasebe bölümünü tercih etmelerinde etkili olan unsurların motivasyonları üzerindeki etkilerini tespit etmeye çalışmıştır. Yapılan analizler sonucunda öğrencilerin bu bölümü tercih etmelerini muhasebe mesleğinin cazibesi, 
bilinçdışı ve meslek lisesi olmak üzere 3 unsurun etkilediği ve muhasebe mesleğinin cazibesi boyutunun öğrencilerin motivasyonu üzerinde büyük bir etkisi olduğu sonucu ortaya çıkmıştır.

Yıldırım vd. (2018, s. 935-951) yaptıkları çalışmalarında meslek yüksekokulu öğrencilerinin muhasebe meslek tercihinde kişisel becerilerinin ve öğrencilerin iş hayatında ki beklentilerini tespit etmeye çalışmışlardır. Çalışma sonucunda muhasebe öğrencilerinin bu bölümü tercih etmelerindeki muhasebe bölümünde iş imkanının çok olmasından dolayı olduğu görülmüştür.

Aksu ve Tosun (2018, s. 17-31) çalışmalarında muhasebe eğitimi gören öğrencilerin akademik başarılarında motivasyon ve mesleki beklentilerin bir etkisinin olup olmadığını tespit etmeye çalışmışlardır. Yapılan bu çalışma sonucunda motivasyon ve mesleki beklentilerin öğrencilerin akademik başarısında etkili olduğu tespit edilmiştir.

Karavardar ve Paça (2019, s. 73-83) çalışmalarında öğrencilerin muhasebeyi algılamaları konusunda öğrencileri etkileyen faktörler ve duydukları kaygı seviyesi üzerinde bir inceleme yapmışlardır. Araştırmada ulaşılan sonuca göre muhasebe dersine karşı öğrencilerin kaygıları olsa dahi muhasebeyi öğrenme kullanma ve meslek edinme konusunda istekli oldukları, muhasebe dersi gördükçe artan bilgileri sonucunda muhasebeye karşı olan düşüncelerinde olumlu yönde değiştiği sonucu ortaya çıkmıştır.

Literatür incelendiğinde üniversite öğrencilerinin eğitimden beklentileri ile ilgili çok sayıda çalışma olduğu görülmüştür. Fakat muhasebe alanında ve özellikle üniversite öncesi lise eğitiminde yapılan bir çalışma olmadığı görülmektedir. Çalışmanın literatürdeki bu boşluğu doldurması beklenmektedir.

\section{ÇALIŞMANIN VERİ SETİ VE ÖNEMI}

Çalışmanın bu kısmında araştırmanın veri seti ve yöntemine ilişkin bilgiler verilmiştir. Çalışmada muhasebe eğitimi gören son sınıf Mesleki ve Teknik Anadolu Lisesi ve Üniversite öğrencilerinin muhasebe eğitiminden beklenti ve motivasyonları, öğrencilere anket uygulanarak araştırılmıştır. Bu çalışma Bryne ve Flood (2005) ve Zeytinoğlu (2012)'nun çalışmalarındaki ölçekten yararlanılarak yapilmıştır.

\section{Veri Seti}

Çalışmada kullanılan veriler 2019 yılında Ağrı İlinde Eğitim Gören Mesleki ve Teknik Anadolu Lisesine ve Ağrı İbrahim Üniversitesi İktisadi ve İdari Bilimler Fakültesi İşletme /İktisat/Siyaset Bilimi ve Kamu Yönetimi son sınıf öğrencilerine anket uygulanarak elde edilmiştir. Çalışmanın evreni olarak Ağrı İlinde muhasebe eğitimi gören lise ve üniversite öğrencileri seçilmiştir. Bu sayı çalışmanın yapıldığı yıl itibari ile 189'dur. Yanlış ve eksik veriler çıkarıldıktan sonra anket uygulanan öğrenci sayısı ise toplam 119 kişidir. Çalışmada evrenin \%63'üne ulaşılmıştır. Bu nedenle örneklemin evreni güçlü olarak temsil ettiği düşünülmektedir. Çalışmada, ankete katılan öğrencilerin demografik özellikleri ile 4 soru, motivasyonları hakkında 18 soru, muhasebe bölümünü seçme nedenleri ile ilgili 7 soru, muhasebe bölümünden beklentiler ile ilgili 7 soru, öğrenim süreci ile ilgili 11 soru, yeteneklerine güven konusunda ise 4 soru yer almaktadır. Anket formunda 47 adet yargı ifadesi bulunmakta olup 5'li likert ölçeği kullanılmıştır. Yapılan analizlere göre veriler normal dağılmıştır (sig:0.000). Anketin güvenilirlik analizi için yapılan Cronbach Alpha $(\alpha)$ analiz değeri ise 0.846 'dır. Bu değer 0.8 ve üzeri olduğu için, uygulanan anketin yüksek güvenilirliğe sahip olduğu söylenebilir.

\section{Yöntem}


Çalışma birebir öğrenciler ile görüşülerek yapılmış olup anket yöntemi ile uygulanmıştır. Elde edilen veriler yüzde ve frekans dağılımı yöntemi ile analiz edilmiştir. Ayrıca t-testi yöntemiyle cinsiyet, staj durumu ve mezuniyet değişkenlerinde ortalamaların anlamlı bir farklılık gösterip göstermediğine de bakılmıştır.

\section{Çalışmanın Sınırlılıkları}

Çalışmada, frekans ve yüzde dağılımı, ortalamalar ve t-testi gibi istatistiki yöntemlerle analizler yapılmıştır. İleriki çalışmalarda ortalamaların farklı değişkenlere göre farkı ve faktör analizleri gibi daha ayrıntılı analizler yapılabilir. Çalışmada kullanılan veriler sadece Ağrı İbrahim Çeçen Üniversitesi ve Ağrı'daki Mesleki ve Teknik Anadolu Lisesinde öğrenim gören öğrencilerden elde edilmiştir. Çalışmada anketlerden yola çıkarak sadece öğrenci görüşlerine yer verilmiştir. İleriki çalışmalarda örneklem büyüklüğü genişletilebilir ve öğrenciler dışında öğreticilerin de görüşleri de alınabilir.

\section{BULGULAR VE YORUMLAR}

Öğrencilerin anket sorularına verdikleri cevaplara ilişskin değerlendirmeler tabloların altında yer almaktadır. Uygulanan ankette ilk olarak demografik özelliklere daha sonra ise araştırmanın yapıtaşını oluşturan öğrencilerin motivasyonları beklentileri ve yükseköğretime hazırlıklarına ilişkin sonuçlara yer verilmiştir.

Tablo 1. Cinsiyet

\begin{tabular}{|c|c|c|}
\hline Cinsiyet & Frekans & Yüzde \\
\hline Kadın & 62 & 52.1 \\
\hline Erkek & 57 & 47.9 \\
\hline Toplam & $\mathbf{1 1 9}$ & $\mathbf{1 0 0}$ \\
\hline
\end{tabular}

Anketin uygulandığı öğrenci sayısı 119 olup bunların \%52.1'ini k1z \%47.9'unu erkek öğrenciler oluşturmaktadır.

Tablo 2.Staj Durumu

\begin{tabular}{|c|c|c|}
\hline Staj Durumu & Frekans & Yüzde \\
\hline Evet & 64 & 53.8 \\
\hline Hayır & 55 & 46.2 \\
\hline Toplam & 119 & 100 \\
\hline
\end{tabular}

Öğrencilerin \%53.8'i staj yapmış olup \%46.2'si hiç staj yapmamıştır. Öğrencilerin yarısından fazlası staj yapmış olup, staj yapan öğrencilerin yapmayan öğrencilere göre muhasebeyi anlama kavrama ve uygulama açısından daha avantajlı oldukları düşünülmektedir

Tablo 3.Muhasebe İlgi Düzeyi

\begin{tabular}{|c|c|c|}
\hline Muhasebe İlgi Düzeyi & Frekans & Yüzde \\
\hline Düşük & 29 & 24.4 \\
\hline Orta & 81 & 68.1 \\
\hline Yüksek & 9 & 7.6 \\
\hline
\end{tabular}




\section{Al-Farabi International Journal on Social Sciences}

\begin{tabular}{|l|l|l|}
\hline Toplam & 119 & 100 \\
\hline
\end{tabular}

Mesleki ve Teknik Anadolu Lisesi ve Üniversite son sınıf muhasebe eğitimi gören 119 öğrenciye yapılan anket sonucunda muhasebeye olan ilgi düzeyleri sırasıyla şöyledir; \%24.4'ü düşük, \%68.1'i orta , \%7.6'sının ise yüksek olduğu tespit edilmiştir. Bu durum muhasebe bölümü okuyan öğrencilerin daha çok muhasebeye olan ilgilerin orta düzeyde olduğu ve muhasebe ilgi düzeyi yüksek olan öğrenci sayının çok az olduğunu göstermektedir.

Tablo 4.Mezun Olduğu Okul

\begin{tabular}{|l|l|l|}
\hline Mezun olduğu okul & Frekans & Yüzde \\
\hline $\begin{array}{l}\text { Mesleki Ve Teknik } \\
\text { Anadolu Lisesi }\end{array}$ & 59 & 49.6 \\
\hline Diğer lise & 60 & 50.4 \\
\hline Toplam & 119 & 100 \\
\hline
\end{tabular}

Ankete katılan öğrencilerin \%49.6'sı Mesleki ve Teknik Anadolu Lisesi \%50.4'ü ise diğer liselerden mezun olmuştur. Mesleki Ve Teknik Anadolu Lisesi öğrencilerinin eğitim hayatlarına muhasebe alanında devam etmeleri durumunda muhasebeyi anlama, yorumlama ve uygulamada daha avantajlı durumda oldukları düşünülmektedir.

Daha sonra ayrıntılı bir şekilde açıklanacak olan anket sorularında verilen cevapları genel olarak incelendiğinde en yüksek ortalamaya sahip 3 cevap üniversite mezunu olmayı gerçekten istiyorum (3.94), kendi gelişimimi değerlendirmek konusunda istekliyim (3.90) ve görevlerimi yerine getirme konusunda kendimden eminim (3.82) olarak tespit edilmiştir. En düşük ortalamaya sahip 3 cevap ise üniversitede hangi bölümü okuduğumun önemli olmadığını düşünüyorum (2.51), bu bölümden mezun olmam spor ve sosyal faaliyetlere katılmamı sağlayacaktır (2.71) ve arkadaşlarımda bu bölümü tercih etmeyi planladı veya planlıyordur (2.88). Ortaya çıkan sonuçlara göre öğrencilerin muhasebe derslerinde başarılı olma konusunda kendilerine güvendikleri ve muhasebe eğitiminin kendilerini iyi bir noktaya taşıyacağı konusunda motive oldukları gözlemlenirken, öğrencilerin bu bölümü tercih etmelerinde sosyal çevre ve sportif faaliyetlerin motive edici olmadığı görülmektedir. 


\section{Al-Farabi International Journal on Social Sciences}

Tablo 5.Motivasyon

\begin{tabular}{|c|c|c|c|c|c|c|}
\hline & 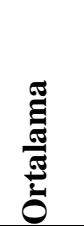 & 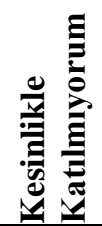 & 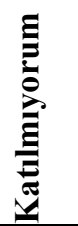 & 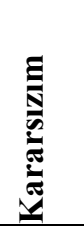 & 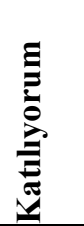 & 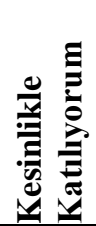 \\
\hline $\begin{array}{l}\text { Bu bölümden mezun olmam gelecekte bana yeni } \\
\text { firsatlar tanıyacaktır. }\end{array}$ & 3.31 & 15.1 & 10.1 & $\overline{19.3}$ & 39.5 & 16.0 \\
\hline $\begin{array}{l}\text { Bu bölümden mezun olmam iyi bir işe girmemi } \\
\text { sağlayacaktır. }\end{array}$ & 3.26 & 7.6 & 17.6 & 26.1 & 37.8 & 10.9 \\
\hline $\begin{array}{l}\text { Bu bölümden mezun olmam entelektüel yeteneklerimi } \\
\text { ve zihnimi zenginleştirecektir. }\end{array}$ & 3.42 & 8.4 & 15.1 & 20.2 & 37.8 & 18.5 \\
\hline $\begin{array}{l}\text { Bu bölümden mezun olmam kazanma gücümü } \\
\text { arttıracaktır. }\end{array}$ & 3.38 & 7.6 & 15.1 & 25.2 & 35.3 & 16.8 \\
\hline $\begin{array}{l}\text { Bu bölümden mezun olmam bana faydalı olacak } \\
\text { bilgileri arttırıp yeteneklerimi geliştirecektir. }\end{array}$ & 3.46 & 5.9 & 16.0 & 22.7 & 37.0 & 18.5 \\
\hline $\begin{array}{l}\text { Bu bölümden mezun olmam daha eğitimli bir insan } \\
\text { olmamı sağlayacaktır. }\end{array}$ & 3.52 & 5.9 & 14.3 & 16.0 & 49.6 & 14.3 \\
\hline $\begin{array}{l}\text { Bu bölümden mezun olmam kariyerim için eğitim } \\
\text { ihtiyaçlarımı karşılayacaktır }\end{array}$ & 3.33 & 9.2 & 10.9 & 28.6 & 39.5 & 11.8 \\
\hline $\begin{array}{l}\text { Bu bölümden mezun olmam muhasebeyi yoğun bir } \\
\text { şekilde öğrenmemi sağlayacaktır. }\end{array}$ & 3.21 & 12.6 & 12.6 & 29.4 & 31.1 & 14.3 \\
\hline $\begin{array}{l}\text { Bu bölümden mezun olmam ufkumu genişletecek ve } \\
\text { zorluklarla yüzleşmemi sağlayacaktır. }\end{array}$ & 3.22 & 12.6 & 13.4 & 23.5 & 39.5 & 10.9 \\
\hline $\begin{array}{l}\text { Bu bölümden mezun olmam yüksek lisans yapmamda } \\
\text { bana yardımcı olacaktır }\end{array}$ & 3.24 & 12.6 & 10.9 & 29.4 & 33.6 & 13.4 \\
\hline $\begin{array}{l}\text { Bu bölümden mezun olmam yeni insanlarla tanışmamı } \\
\text { sağlayacaktır. }\end{array}$ & 3.59 & 8.4 & 9.2 & 20.2 & 38.7 & 23.5 \\
\hline $\begin{array}{l}\text { Bu bölümden mezun olmam spor ve sosyal faaliyetlere } \\
\text { katılmamı sağlayacaktır. }\end{array}$ & 2.71 & 16.8 & 27.7 & 31.1 & 16.0 & 8.4 \\
\hline $\begin{array}{l}\text { Bu bölümden mezun olmam üniversitede başarılı } \\
\text { olarak kendimi kanıtlamamı sağlayacaktır }\end{array}$ & 3.22 & 11.8 & 16.0 & 22.7 & 37.0 & 12.6 \\
\hline Üniversite mezunu olmayı gerçekten istiyorum & 3.94 & 10.1 & 2.5 & 14.3 & 29.4 & 43.7 \\
\hline $\begin{array}{l}\text { Bu bölümden mezun olmam aktif bir sosyal yaşam } \\
\text { fırsatı sağlayacaktır. }\end{array}$ & 3.25 & 10.9 & 13.4 & 31.1 & 28.6 & 16.0 \\
\hline $\begin{array}{l}\text { Bu bölümden mezun olmam kendime güvenmemi } \\
\text { sağlayacaktır }\end{array}$ & 3.45 & 9.2 & 11.8 & 23.5 & 35.3 & 20.2 \\
\hline $\begin{array}{l}\text { Bu bölümden mezun olmam diğer insanların benden } \\
\text { beklentilerini karşılamamı sağlayacaktır }\end{array}$ & 3.39 & 7.6 & 14.3 & 27.7 & 31.9 & 18.5 \\
\hline $\begin{array}{l}\text { Bu bölümden mezun olmam kendimi daha iyi } \\
\text { anlamamı sağlayacaktır. }\end{array}$ & 3.31 & 10.1 & 13.4 & 27.7 & 32.5 & 16.0 \\
\hline
\end{tabular}

Tablo 5'de görüldüğü üzere anket uygulanan öğrencilerin muhasebe eğitiminde en çok motive oldukları konu 3.94 ortalama ile "Üniversite mezunu olmayı gerçekten istiyorum" ifadesidir. İkinci en çok motive oldukları konu ise 3.59 ortalama ile "Bu bölümden mezun olmam yeni insanlarla tanışmamı sağlayacaktır" ifadesidir.

Motivasyonlarına en az etki eden konu ise bölümden mezun olmanın sosyal sporsal faaliyetlere etkisidir diyebiliriz. Anket sorularına verilen cevaplara göre öğrenciler üniversiteyi kazanma ve mezun olma konusunda isteklidir. Öğrencilerin gelecekte muhasebe alanında kendilerini geliştirmek istemesi ve bu bölümün onlara bir çevre kazandıracağı düşüncesi öğrencilerin motivasyonlarını artıran unsurlar olarak görülmektedir. Öğrencilerin muhasebe alanını tercih etmelerinde spor ve sosyal faaliyetlerin etkili olmadığı görülmüştür. Ülkemizde muhasebe eğitimi gören öğrencilerin 
sosyal veya spor faaliyet alanlarını geliştirecek herhangi bir ders görmemeleri öğrencilerin bu konuda herhangi bir beklentiye girmemelerine sebep olduğu düşünülmektedir.

Tablo 6.Öğrencilerin Muhasebe Bölümünü Seçme Nedenleri

\begin{tabular}{|c|c|c|c|c|c|c|}
\hline & 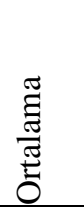 & 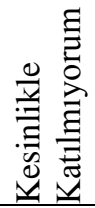 & 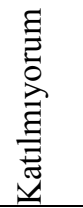 & 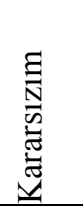 & 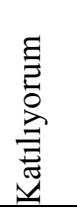 & 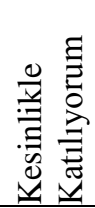 \\
\hline SMMM olmayı çok istiyorum. & 2.97 & 20.2 & 10.9 & 35.3 & 18.5 & 15.1 \\
\hline $\begin{array}{l}\text { Yeteneklerimin ve becerimin muhasebeye } \\
\text { yatkın } \\
\text { olduğunu düşünüyorum. }\end{array}$ & 3.1 & 14.3 & 15.1 & 21.0 & 38.7 & 10.9 \\
\hline $\begin{array}{l}\text { Muhasebe alanındaki kariyer firsatları ilgimi } \\
\text { çekiyor. }\end{array}$ & 3.10 & 16.8 & 11.8 & 27.7 & 31.9 & 11.8 \\
\hline Muhasebeden hoşlanıyorum & 3.11 & 16.0 & 13.4 & 25.2 & 33.6 & 11.8 \\
\hline $\begin{array}{l}\text { Muhasebe hakkında daha çok şey öğrenmek } \\
\text { istiyorum. }\end{array}$ & 3.39 & 16.0 & 7.6 & 20.2 & 33.6 & 22.7 \\
\hline $\begin{array}{l}\text { Arkadaşlarımda bu bölümü tercih etmeyi } \\
\text { planladı / planlıyor }\end{array}$ & 2.88 & 22.7 & 11.8 & 30.3 & 25.2 & 10.1 \\
\hline $\begin{array}{l}\text { Üniversitede hangi bölümü okuduğumun } \\
\text { önemli olmadığını düşünüyorum }\end{array}$ & 2.51 & 39.5 & 16.8 & 11.8 & 16.8 & 15.1 \\
\hline
\end{tabular}

Tablo 6'da lise ve üniversite son sınıf öğrencileri ile yaptığımız anket cevaplarının frekansları yer almaktadır. En çok (3.39) ortalamaya sahip "muhasebe hakkında daha çok şey öğrenmek istiyorum" ifadesi yer alırken ikinci sirada (3.16) ortalama ile "Yeteneklerimin ve becerilerimin muhasebeye yatkın olduğunu düşünüyorum" ifadesi ve son olarak en düşük (2.51) ortalama ile "Üniversitede hangi bölümü okuduğumun önemi olmadığını düşünüyorum ifadesi yer almaktadır”. Ortaya çıkan sonuçlar değerlendirildiğinde öğrencilerin muhasebe hakkında daha çok şey öğrenmek istedikleri ve muhasebe dersinde yetenekli ve becerikli oldukları konusunda kendilerine güvendikleri tespit edilmiştir. Üniversitede tercihlerinin bilinçli bir şekilde yaptıkları ve yapacakları düşünülmektedir.

Tablo 7. Muhasebe Bölümünden Beklentiler

\begin{tabular}{|l|l|l|l|l|l|l|}
\hline & & & & \\
\end{tabular}


Tablo 7'de görüldüğü üzere anketin uygulandığı Mesleki ve Teknik Anadolu Lisesi ve Üniversite öğrencilerinin muhasebe bölümünden beklentileri ile ilgili cevapları değerlendirdiğimizde 3.62 ile en yüksek ortalamaya sahip ifadenin "Bu bölümden mezun olunca kendime olan güvenimi arttıracağım" olduğu görülürken, 3.51 ortalama ile ikinci sırada "bu bölümden mezun olunca yeni insanlarla tanışacağım" ifadesi yer almaktadır. En düşük 3.22 ortalamaya sahip ifade ise "Bu bölümden mezun olunca yeni yetenekler elde edeceğim" ifadesi olmuştur. Bu sonuçlara bakarak, öğrencilerin muhasebe bölümünden mezun olmaları halinde özgüvenlerinin artacağı ve daha fazla insanlar tanışacakları düşüncesine sahiptirler diyebiliriz. En düşük ortalamaya sahip olan yeni yetenekler elde edeceğim ifadesi ile öğrencilerin muhasebe bölümünün onlara herhangi bir yetenek katacaklarını düşünmedikleri ve muhasebeyi herkesin yapabileceği bir iş olarak benimsedikleri ortaya çıkmıştır.

Tablo 8.Öğrenim Süreci

\begin{tabular}{|c|c|c|c|c|c|c|}
\hline & 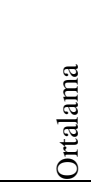 & 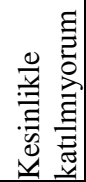 & 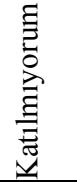 & 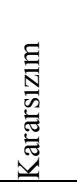 & 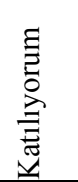 & 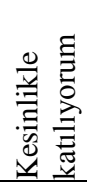 \\
\hline Derslere girmek konusunda istekliyim. & 3.10 & 13.4 & 19.3 & 21.0 & 36.1 & 10.1 \\
\hline $\begin{array}{l}\text { Kendi yaşamımı organize etmek } \\
\text { konusunda istekliyim. }\end{array}$ & 3.68 & 9.2 & 6.7 & 16.0 & 42.9 & 25.2 \\
\hline $\begin{array}{l}\text { Öğretim elemanlarından yardım almak } \\
\text { konusunda istekliyim. }\end{array}$ & 3.47 & 10.1 & 8.4 & 24.4 & 37.8 & 19.3 \\
\hline $\begin{array}{l}\text { Görevlerimi yerine getirme konusunda } \\
\text { kendimden eminim. }\end{array}$ & 3.82 & 4.2 & 7.6 & 18.5 & 41.2 & 28.6 \\
\hline $\begin{array}{l}\text { Kendi kendime öğrenme konusunda } \\
\text { sorumluluk almaya hazırım. }\end{array}$ & 3.68 & 6.7 & 6.7 & 25.2 & 33.6 & 27.7 \\
\hline $\begin{array}{l}\text { Zamanımı etkin olarak kullanmak için } \\
\text { planlı çalışmaya hazırım. }\end{array}$ & 3.51 & 6.7 & 9.2 & 27.7 & 38.7 & 17.6 \\
\hline $\begin{array}{l}\text { Kendi gelişimimi değerlendirmek } \\
\text { konusunda istekliyim }\end{array}$ & 3.90 & 3.4 & 4.2 & 19.3 & 44.5 & 28.6 \\
\hline $\begin{array}{l}\text { Grup halinde çalışmak konusunda } \\
\text { istekliyim. }\end{array}$ & 3.57 & 7.6 & 7.6 & 27.7 & 34.5 & 22.7 \\
\hline $\begin{array}{l}\text { Benden akademik olarak beklenenler } \\
\text { konusunda bilinçliyim. }\end{array}$ & 3.36 & 13.4 & 8.4 & 23.5 & 37.8 & 16.8 \\
\hline $\begin{array}{l}\text { Bağımsız olarak çalışma konusunda } \\
\text { istekliyim. }\end{array}$ & 3.54 & 9.2 & 6.7 & 21.0 & 46.2 & 16.8 \\
\hline $\begin{array}{l}\text { Bilgisayar kullanma konusundaki } \\
\text { yeteneklerimin farkındayım. }\end{array}$ & 3.60 & 8.4 & 5.0 & 24.4 & 42.0 & 20.2 \\
\hline
\end{tabular}

Tablo 8'de ankete katılan öğrencilerin verdiği cevaplar incelendiğinde (3.90) en yüksek ortalama "Kendi gelişimimi değerlendirmek konusunda istekliyim" ifadesi olurken ikinci sırada 3.82 ortalama ile "Görevlerimi yerine getirme konusunda kendimden eminim" ifadesi ve son sirada ise 3.10 ortalamaya sahip "derslere girmek konusunda istekliyim" ifadesi yer aldığı görülmektedir. Anket sonucu değerlendirildiğinde öğrencilerin verilen ödevleri yapma ve kendilerini bu alanda geliştirmek için ilgili kaynaklardan yararlanmak konusunda istekli oldukları tespit edilmiştir. Bu sonuçlar içerisinde ülkemizdeki temel sorunlardan biri olan uzun ders saatlerinin, öğrencilerin derse girmeleri konusundaki isteklerini olumsuz etkilediği görülmüştür. 


\section{Al-Farabi International Journal on Social Sciences}

Tablo 9.Kendine Güven

\begin{tabular}{|c|c|c|c|c|c|c|}
\hline & 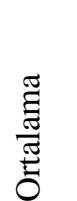 & 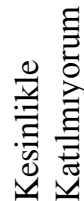 & 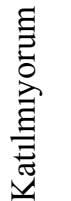 & 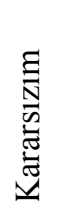 & 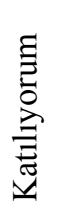 & 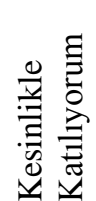 \\
\hline $\begin{array}{l}\text { Derslerle baş edebilme } \\
\text { konusunda kendime } \\
\text { güveniyorum }\end{array}$ & 3.52 & 10.9 & 13.4 & 15.1 & 32.8 & 27.7 \\
\hline $\begin{array}{l}\text { Tüm sınavları ilk seferde } \\
\text { geçme konusunda kendime } \\
\text { güveniyorum }\end{array}$ & 3.32 & 11.8 & 12.6 & 25.2 & 31.9 & 18.5 \\
\hline $\begin{array}{l}\text { Sinıfta \% } 10 \text { ’luk dilime } \\
\text { gireceğim konusunda } \\
\text { kendime güveniyorum }\end{array}$ & 3.41 & 11.8 & 13.4 & 21.8 & 27.7 & 25.2 \\
\hline $\begin{array}{l}\text { Sınıf ortalamasının üstünde } \\
\text { not alacağım konusunda } \\
\text { kendime güveniyorum }\end{array}$ & 3.45 & 10.9 & 12.6 & 22.7 & 27.7 & 26.1 \\
\hline
\end{tabular}

Tablo 9'daki anket sonuçlarını değerlendirdiğimizde öğrencilerin kendilerine güven konusunda kararsız ve sınavlar için kaygılı oldukları görülmüştür. Öğrencilerin kaygılı olmalarındaki en büyük etkenin, rakiplerine karşı kendilerini yetersiz hissetmeleri ve derece yapma konusunda kendilerine güvenmemeleri olduğu düşünülmektedir.

Tablo 10. T-testi Sonuçları

\begin{tabular}{|c|c|c|c|}
\hline & $\begin{array}{l}\text { Cinsiyet } \\
(\mathrm{K} 1 \mathrm{z} / \text { Erkek })\end{array}$ & $\begin{array}{l}\text { Staj Durumu } \\
\text { (Yapıyor/Yapmiyor) }\end{array}$ & $\begin{array}{l}\text { Mezuniyet } \\
\text { (Meslek } \\
\text { Liseli/Diğer } \\
\text { Lise }\end{array}$ \\
\hline Motivasyon & $\begin{array}{l}\text { Gruplar arası } \\
\text { anlamlı bir fark } \\
\text { yoktur } \mathrm{p}>0.05 \text { ) }\end{array}$ & $\begin{array}{l}\text { Gruplar arası } \\
\text { anlamlı bir fark } \\
\text { yoktur } \mathrm{p}>0.05 \text { ) }\end{array}$ & $\begin{array}{l}\text { Gruplar aras1 } \\
\text { anlamlı bir fark } \\
\text { yoktur } \mathrm{p}>0.05 \text { ) }\end{array}$ \\
\hline $\begin{array}{l}\text { Öğrencilerin Muhasebe } \\
\text { Bölümünü Seçme Nedenleri }\end{array}$ & $\begin{array}{l}\text { Gruplar arası } \\
\text { anlamlı bir fark } \\
\text { yoktur } \mathrm{p}>0.05 \text { ) }\end{array}$ & $\begin{array}{l}\text { Gruplar arası } \\
\text { anlamlı bir fark } \\
\text { yoktur } \mathrm{p}>0.05 \text { ) }\end{array}$ & $\begin{array}{l}\text { Gruplar aras1 } \\
\text { anlamlı bir fark } \\
\text { yoktur } p>0.05 \text { ) }\end{array}$ \\
\hline $\begin{array}{l}\text { Muhasebe Bölümünden } \\
\text { Beklentiler }\end{array}$ & $\begin{array}{l}\text { Gruplar arası } \\
\text { anlamlı bir fark } \\
\text { yoktur } \mathrm{p}>0.05 \text { ) }\end{array}$ & $\begin{array}{l}\text { Gruplar arası } \\
\text { anlamlı bir fark } \\
\text { yoktur } \mathrm{p}>0.05 \text { ) }\end{array}$ & $\begin{array}{l}\text { Gruplar arası } \\
\text { anlamlı bir } \\
\text { fark } \\
\text { bulunmuştur } \\
\text { p<0.05) }\end{array}$ \\
\hline Öğrenim Süreci & $\begin{array}{l}\text { Gruplar arası } \\
\text { anlamlı bir fark } \\
\text { yoktur } \mathrm{p}>0.05 \text { ) }\end{array}$ & $\begin{array}{l}\text { Gruplar arası } \\
\text { anlamlı bir fark } \\
\text { yoktur } \mathrm{p}>0.05 \text { ) }\end{array}$ & $\begin{array}{l}\text { Gruplar arası } \\
\text { anlamlı bir fark } \\
\text { yoktur } p>0.05 \text { ) }\end{array}$ \\
\hline Kendine Güven & $\begin{array}{l}\text { Gruplar arası } \\
\text { anlamlı bir fark } \\
\text { yoktur } \mathrm{p}>0.05 \text { ) }\end{array}$ & $\begin{array}{l}\text { Gruplar arası } \\
\text { anlamlı bir fark } \\
\text { bulunmuştur } \\
\text { p<0.05) }\end{array}$ & $\begin{array}{l}\text { Gruplar arası } \\
\text { anlamlı bir } \\
\text { fark } \\
\text { bulunmuştur } \\
\text { p<0.05) }\end{array}$ \\
\hline
\end{tabular}

Ortaya çıkan sonuçlara göre, öğrencilerin cinsiyetleri ile motivasyon, muhasebe bölümünü seçme nedenleri, muhasebe bölümünden beklentileri, öğrenim süreçleri ve kendilerine güveni arasında anlamlı bir farka rastlanmamıştır $(\mathrm{p}>0.05)$. Fakat staj yapan öğrenciler ile yapmayan öğrenciler arasında kendilerine güven bakımından anlamlı bir fark olduğu görülmüştür $(p<0.05)$. Ortalama puanlara bakıldığında, staj yapan öğrencilerin kendilerine, yapmayan öğrencilere göre daha fazla güvendiği görülmüştür. Ayrıca öğrencilerin meslek lisesi mezunu olması veya olmaması ile 
muhasebe bölümünden beklentileri ve kendileri güvenleri arasında da anlamlı bir fark olduğu $(p<0.05)$ tespit edilmiştir. Ortalama puanlara göre, meslek lisesi mezunlarının diğer lise mezunlarına göre muhasebe bölümünden beklentileri ve kendilerine güvenleri daha yüksektir (Tablo 10).

\section{SONUÇ VE ÖNERİLER}

Çalışma İbrahim Çeçen Üniversitesi İktisadi ve İdari Bilimler Fakültesi / İşletme / İktisat / Siyaset Bilimi ve Kamu Yönetimi ve Ağrı Semerkant Mesleki Ve Teknik Anadolu Lisesi son sınıf muhasebe eğitimi almakta olan öğrenciler üzerinde yapılmıştır. Öğrencilerin muhasebe eğitiminden beklenti ve motivasyon düzeyleri incelenmiştir. Aynı zamanda bu bölümü seçme nedenleri, eğitim sürecine hazırlıklı olma ve öğrencilerin kendilerine ne kadar güvendiklerine yönelik incelemeler yapılmıştır.

Elde edilen verilerin analiz sonuçlarına göre öğrencilerin üniversiteden mezun olma konusunda motivasyonlarının yüksek olduğu, muhasebe hakkında daha çok şey öğrenmek istedikleri ve bu bölümden mezun olunca kendilerine olan güvenlerinin arttığ 1 , kendilerini geliştirmek için istekli oldukları, fakat kendilerine güven konusunda kararsız, sınavlar içinse kaygılı oldukları görülmüştür. Ayrıca mezuniyet değişkeni açısından, öğrencilerin muhasebe dersinden beklentileri ve kendine güvenleri arasında ve staj yapma değişkeni açısından da sadece kendine güvenleri arasında ortalamalar bakımından anlamlı farklılıklar bulunmuştur. Staj yapan ve meslek lisesinden mezun olan öğrenciler kendilerine daha fazla güvendikleri ve meslek lisesinden mezun olan öğrencilerin muhasebe eğitiminden beklentilerinin daha fazla olduğu tespit edilmiştir.

Çalışmada, öğrencilerin motivasyon ve beklentilerinin orta düzeyin biraz üstünde olduğu tespit edilmiştir. Ortaya çıkan sonuçlara göre, öğrenciler muhasebe bölümünü üniversite mezunu olmak için bir araç olarak görmekte bu yüzden seçmektedir. Ülkemizde muhasebe eğitimi veren bölümlerin giriş puanın gün geçtikçe düşmesinin ve çok sayıda bu bölümle alakalı eğitim veren okulların olmasının, ögrrencilerin bu bölümü seçmelerinde etkili olduğu söylenebilir. Üniversitelerin muhasebe eğitimi veren bölümlerine girişin çok kolay olması, bu bölümlerin niteliğini düşürmüştür diyebiliriz. Artık öğrencilerin, muhasebe bölümlerini bilerek, isteyerek ve bilinçli bir şekilde değil de, sadece lise ve üniversite mezunu olmak konusunda bir basamak olarak görmelerinden dolayı tercih ettikleri tespit edilmiştir. $\mathrm{Bu}$ problemlerin azalması için Lise ve Üniversite de muhasebe eğitimi ile alakalı bölümlerin talep görmeyenlerin kapatılması veya kontenjanların azaltılması gerekebilir. Geri kalan eğitim kurumlarında ise muhasebe eğitimine yönelik öğrencilerin beklentileri ve motivasyonlarını artıracak unsurlar tespit edilerek, öğrenciyi eğitim sürecine daha istekli bir şekilde dahil etmek için çabalanmalı ve muhasebe bölümünün bir araç olmaktan çıkıp öğrenci için bir amaca dönüşmesi noktasında çalışmalarda bulunulmalıdır.

\section{KAYNAKÇA}

Acat, M. B., \& Yenilmez, K. (2004). Eğitim Fakültesi Öğrencilerinin Öğretmenlik Mesleğine İlişkin Motivasyon Düzeyleri. Manas Sosyal Bilimler Dergisi, 2, 125-139.

Aksoy, C., \& Özkan, F. (2015). "Ticaret Meslek Lisesi Muhasebe Bölümü Öğrencilerinin İşletmelerde Beceri Eğitimi Uygulaması, Gaziantep İlinde Bir Alan Araştırması". Bartın Üniversitesi İ.̇̇.B.F. Dergisi, 283-305.

Aksoy, C., \& Özkan, F. (2015). Ticaret Meslek Lisesi Muhasebe Bölümü Öğrencilerinin İşletmelerde Beceri Eğitimi Uygulaması ,Gaziantep İlinde Bir Alan Araştırması. Bartın Üniversitesi İ.İ.B.F. Dergisi, 283-305.

Aksu, İ., \& Tursun, M. (2018). "Muhasebe Eğitimi Alan Öğrencilerin Motivasyon ve Beklenti Düzeylerinin Akademik Başarılarına Etkisi". Akademik Yaklaşımlar Dergisi, 17-31. 
Aytaç, S., \& Dursun, S. (2012). Üniversite Öğrencilerinin İşgücü Piyasasına Yönelik Beklentileri Ve İş Deneyimleri İle Umutsuzluk Ve Kaygı Düzeyleri Arasındaki İlişki Üzerine Bir Araştırma. Celal Bayar Üniversitesi Sosyal Bilimler Dergisi, 373-388.

Byrne, M., \& Flood, B. (2005). "A study of accounting students' motives, expectations and preparedness for higher education". Journal of Further and Higher Education, 111-124.

Cook, A., \& Leckey, J. (1999). Do Expectations Meet Reality? A Survey of Change in the First Year Student Opinion. Journal of Further and Higher Education, 23, 157-170.

Çarıkçı, O. (2017). "Muhasebe Eğitimi Almakta Olan Öğrencilerin Motivasyonları ve Muhasebe Bölümünü Tercihlerinin İrdelenmesi". Süleyman Demirel Üniversitesi İktisadi ve İdarı Bilimler Fakültesi Dergisi, 1223-1233.

Donald, J. G. (1999). Motivation for Higher-Order Learning. New Directions for Teaching and Learning, 78, 27-35.

İbicioğlu, H., Özdaşlı, K., Dalğar, H., \& Yılmaz, T. (2013). "Muhasebe Meslek Mensuplarının İçsel Ve Dişsal Motivasyon Düzeylerinin Tespitine Yönelik Bir Araştırma". Mehmet Akif Ersoy Üniversitesi Sosyal Bilimler Enstitüsü Dergisi, 93-105.

İmamoğlu, A. (2016). Genel Muhasebe 1.

Karavardar, A., \& Paça, M. (2019). "Muhasebe Dersine İlişkin Alg1 ve Kaygı: Giresun Üniversitesi İşletme Bölümü Öğrencileri Üzerinde Bir İnceleme". Gümüşhane Üniversitesi Sosyal Bilimler Enstitüsü Elektronik Dergisi, 73-83.

Kaya, U. (2007). "İlk Defa Muhasebe Dersi Alan Öğrencilerin Derse Yönelik Algılamaları Üzerine Bir Alan Araştırması: Karadeniz Teknik Üniversitesi Örneği". Muhasebe ve Finansman Dergisi, 125133.

Saemann, \& Crooker. (1999). "Student perceptions of the profession and its". Journal of Accounting Education, 1-22.

Şahin, İ., Zoraloğlu, Y. R., \& Fırat, N. Ş. (2011). "Üniversite Öğrencilerinin Yaşam Amaçları, Eğitsel Hedefleri, Üniversite Öğreniminden Beklentileri ve Memnuniyet Durumları". Kuram ve Uygulamada Eğitim Yönetimi [Educational Administration:Theory and Practice], 429-452.

Tan, Mei, L., \& Fawzi, L. (2006). "Students' Beliefs, Attitudes and Intentions to". Accounting Education:, 167-187.

Taylor, J., \& Mander, A. (2007). Studying at University: Early Perceptions and Experiences of First Year Service Mathematics Students. Studies in Learning Evaluation Innovation and Development, 4(3), 29-43.

Yıldırım, G., Güngör, A., \& Kocamış, T. U. (2018). "Muhasebe Eğitimi Alan Öğrencilerin Muhasebe Mesleğini Seçmelerinde Kişisel Becerilerinin Ve İş Hayatından Beklentilerinin Etkisinin Araştırılması". Busıness \& Management Studıes: An Internatıonal Journal, 935-951.

Zeytinoğlu, E. (2012). "Muhasebe Bölümü Öğrencilerinin Motivasyonu ve Beklentileri Üzerine Bir Araştırma: Dumlupınar Üniversitesi Örneği". Muhasebe ve Finansman Dergisi, 103-116. 